Editor's Note: These short reviews of a recent paper in the Journal, written exclusively by graduate students or postdoctoral fellows, are intended to mimic the journal clubs that exist in your own departments or institutions. For more information on the format and purpose of the Journal Club, please see http://www.jneurosci.org/misc/ifa_features.shtml.

\title{
Refining Our Understanding of NgR1 Function during Myelin Inhibition
}

\author{
Gino B. Ferraro \\ Department of Neurology and Neurosurgery, Montreal Neurological Institute, 3801 Rue University, Montreal, Quebec, Canada H3A 2B4 \\ Review of Chivatakarn et al. (http://www.jneurosci.org/cgi/content/full/27/27/7117)
}

Although neurons have the inherent potential to regenerate their neurites, the mature CNS environment is not permissive for neurite outgrowth after injury. Both myelin debris and the astroglial scar actively inhibit regeneration by challenging the severed axon with inhibitory proteins that signal to the axon and prevent growth. Several inhibitory proteins have been identified in inhibitory fractions of myelin including Nogo-A, myelinassociated glycoprotein (MAG) and oligodendrocyte myelin glycoprotein (OMgp). Interestingly, these myelinassociated inhibitors (MAIs) can signal through a common receptor present on neurons, the Nogo-66 receptor 1 (NgR1). Thus, NgR1 has become an attractive target to promote CNS regeneration.

NgR1 activity has been neutralized by several approaches. Experiments with peptide antagonists of NgR1 and a dominant-negative mutant of NgR1 demonstrated promising results in reversing myelin inhibition in vitro and in vivo ( $\mathrm{Ta}-$ ble 1). However, subsequent studies examining CNS repair in two independent NgR1-null mice strains failed to fully support the expectations raised by the molecular antagonists to NgR1. Kim et al. (2004) demonstrated that NgR1 ablation reversed growth cone collapse of dorsal

Received July 27, 2007; revised Aug. 29, 2007; accepted Sept. 3, 2007

Correspondence should be addressed to Gino B. Ferraro, Department of Neurology and Neurosurgery, Montreal Neurological Institute, 3801 Rue University, Montreal, Quebec, Canada H3A 2B4. E-mail: Gino.ferraro@mail.mcgill.ca.

DOI:10.1523/JNEUROSCI.3419-07.2007

Copyright $\odot 2007$ Society for Neuroscience $\quad$ 0270-6474/07/2711451-02\$15.00/0 root ganglion (DRG) neurons in vitro, but they did not assess the effect of NgR1 ablation on neurite outgrowth. They also observed enhanced regeneration of raphespinal and rubrospinal tracts and locomotor recovery in NgR1-null mice after spinal cord injury. Zheng et al. (2005) did not observe an effect of NgR1 ablation on neurite outgrowth of cerebellar or DRG neurons, but they did not assess growth cone collapse. Neither group detected long-distance regeneration of corticospinal tract (CST) axons in a dorsal hemisection model raising some controversy regarding the in vivo role of NgR1 in myelin inhibition and global CNS regeneration. One plausible explanation for this discrepancy is that NgR1 activation is essential for growth cone (GC) collapse, but not long distance growth inhibition. However, this explanation would require cell type-specific effects because raphespinal and rubrospinal tract regeneration was improved in NgR1-null mice.

In a recent paper in The Journal of Neuroscience, Chivatakarn et al. (2007) tackled this issue using two knockdown techniques to address whether NgR1 signaling is necessary for MAI-dependent growth cone collapse and neurite growth inhibition. In outgrowth assays using Chinese hamster ovary cells expressing MAG and substrate-bound OMgp, axons from cerebellar, DRG, and cortical neurons of NgR1-null mice did not show enhanced growth [Chivatakarn et al. (2007), their Figs. 1, (http://www.jneurosci.org/cgi/ content/full/27/27/7117/F1), 2 http:// www.jneurosci.org/cgi/content/full/27/
27/7117/F2), 3D (http://www.jneurosci. org/cgi/content/full/27/27/7117/F3) and supplemental Fig. 1 (http://www.jneurosci. org/cgi/content/full/27/27/7117/DC1)]. Notably, the authors restricted their analysis to neurons with processes equal or longer than one cell body diameter. This differs from several studies that assess the percentage of cells with neurites greater than one or more cell body diameter or total neurite outgrowth per cell (GrandPre et al., 2002; Vyas et al., 2002; Wang et al., 2002; Winton et al., 2002). Although one may argue that outgrowth of $<1$ cell body diameter is not "long distance" outgrowth, it is difficult to extrapolate the outgrowth from an overnight in vitro assay to longer term in vivo studies. Substrate-bound MAIs can reduce and/or completely inhibit neurite outgrowth, thus reanalyzing the data using a different methodology might unmask a subtle effect of NgR1 removal. Although the developmental stage, substrate, and the type of neurons used in these assays varied, the same phenotype was observed. These results suggest that $\mathrm{NgR} 1$ is not required for MAI-dependent inhibition of cerebellar, DRG, and cortical neurite growth.

To address the possibility of compensatory changes in the NgR1-null mouse, Chivatakarn et al. (2007) used shRNAmediated knockdown of NgR1. NgR1 knockdown failed to reverse MAGdependent inhibition [Chivatakarn et al. (2007), their Fig. 3 (http://www.jneurosci. org/cgi/content/full/27/27/7117/F3)]. Although this result seems to differ from previous observations demonstrating that 
Table 1. Summary of various approaches used to neutralize NgR1

\begin{tabular}{|c|c|c|c|c|}
\hline \multirow[b]{2}{*}{ Strategy } & \multicolumn{2}{|l|}{ In vitro } & \multicolumn{2}{|l|}{ In vivo } \\
\hline & GC collapse & Neurite outgrowth & Axon regeneration & Behavioral recovery \\
\hline NEP1- $40^{a}$ & E12 chick DRG with Nogo-66 & E12 chick DRG on myelin & Corticospinal tract & Locomotor \\
\hline $\mathrm{NgR}(1-310)$ ecto $^{b, c}$ & ND & E13 chick DRGs on Nogo- 66 and myelin & Corticospinal and raphespinal tracts & Locomotor \\
\hline $\mathrm{DN}-\mathrm{NgR} 1^{d, e}$ & ND & $\begin{array}{l}\text { P7-P9 mouse CGNs on Nogo-66, MAG, 0MGp, and } \\
\text { myelin }\end{array}$ & Growth-stimulated retinal ganglion cells & ND \\
\hline NgR1-null mice ${ }^{f, g}$ & P6 DRGs with Nogo-66, MAG, 0MGp, and myelin & ND & $\begin{array}{l}\text { Raphespinal and rubrospinal tracts }{ }^{f} \text { and } \\
\text { corticospinal fibers }{ }^{g}\end{array}$ & Locomotor $^{f}$ \\
\hline NgR1-null mice ${ }^{h}$ & ND & $\begin{array}{l}\text { No reversal for P7 CGNs and P10 DRG neurons on } \\
\text { Nogo- } 66 \text { and myelin }\end{array}$ & No corticospinal tract regeneration & No recovery \\
\hline
\end{tabular}

To assess the effects of $\mathrm{NgR} 1$ on long-distance regeneration and functional recovery in (NS injury models, NgR1 activity has been neutralized by several approaches. The small Nogo-66 (1-40) antagonist peptide (NEP 1- 40) is a competitive antagonist of the Nogo-66 binding site of NgR. The soluble ligand-binding domain of NgR1 [ $\mathrm{NgR(310)ecto]} \mathrm{cannot} \mathrm{interact} \mathrm{with} \mathrm{coreceptors.} \mathrm{A} \mathrm{dominant-negative} \mathrm{form} \mathrm{of} \mathrm{NgR} \mathrm{(DN-NgR)} \mathrm{lacks} \mathrm{the} \mathrm{last} 136$ aa in the C-terminal domain, which prevents NgR1 binding to coreceptors such as $\mathrm{p75}$. Most of the neurons used in these studies are cerebellar granule neurons (CGNs) and DRG neurons. E, Embryonic day; ND, not determined. ${ }^{a} \mathrm{GrandPre}$ et al., 2002. ${ }^{b}$ Fournier et al., 2002. ${ }^{\complement} \mathrm{Li}$ et al., 2004. ${ }^{d}$ Wang et al., 2002. ${ }^{~}$ Fischer et al., 2004. ${ }^{f}$ Kim et al., 2004. ${ }^{g}$ Cafferty and Strittmatter, 2006. ${ }^{h}$ Zheng et al., 2005.

siRNA-mediated knockdown of NgR1 promoted DRG outgrowth on myelin, there are several differences between the two studies (Ahmed et al., 2005). Most notable are differences in inhibitory substrates; Ahmed et al. (2005) applied soluble myelin whereas Chivatakarn et al. (2007) grew neurons in the presence of MAG. This could be important because MAG also signals through NgR2 and MAG accounts for a small proportion of the inhibitory activity of total myelin. NgR1 signaling may be sufficient for MAI-induced inhibition in some neuronal types and not others. Although MAG- and OMgp-dependent neurite outgrowth inhibition was not attenuated in DRGs derived from the NgR1 null mice, the incomplete knockdown achieved with shRNAi complicates the interpretation [Chivatakarn et al. (2007), their Fig. 3B (http://www. jneurosci.org/cgi/content/full/27/27/ 7117/F3)]. The efficacy of the shRNAdependent knockdown of NgR1 could be assessed by treating cells with various MAIs and assessing levels of RhoA activation.

Although concluding that NgR1 is not required to inhibit axonal growth in the presence of MAIs, Chivatakarn et al. (2007) also revisited the role of NgR1 during growth-cone collapse. GC collapse was significantly reversed in DRGs of NgR1-null mice when presented with MAG and OMgp, but not Sema3A [Chivatakarn et al. (2007), their Fig. 4 (http:// www.jneurosci.org/cgi/content/full/27/ 27/7117/F4)]. These results support previous observations (GrandPre et al., 2002; Kim et al., 2004). The inhibition obtained in this assay leaves a small window for reversal of inhibition; however, these are difficult experiments to perform because of the high basal GC collapse and poor growth of postnatal day 25 DRG explants. It would be interesting to complement this data with a growth cone collapse assay using CNS neurons. Nevertheless, Chi- vatakarn et al. (2007) used adult DRGs in the outgrowth and GC collapse assays, demonstrating a distinction between MAI-mediated GC collapse and neurite outgrowth inhibition.

Chivatakarn et al. (2007) have neatly consolidated opposing interpretations of in vitro data examining MAI responses of neurons from two strains of NgR1 knock-out mice. Although it is still premature to conclude that NgR1 mediates GC collapse but not neurite outgrowth inhibition in all neurons and in response to each MAI, the idea that collapse and neurite outgrowth inhibition are mechanistically dissociated is intriguing. The data presented here does raise some interesting issues. If $\mathrm{NgR} 1$ is not required for neurite outgrowth inhibition, then how does one explain the longdistance regeneration of the raphespinal and rubrospinal tracts seen in the NgR1null mice (Kim et al., 2004)? Although NgR1 activity is required for MAI-induced inhibition in some neurons, it is plausible that another yet unidentified receptor mediates inhibition in other neurons. Outgrowth assays using neurons from the red and raphe nuclei could test this idea. However, NgR1 may be required for MAI-induced neurite outgrowth inhibition of additional neuronal populations in vivo because a pervious study has shown regeneration of the CST axons after unilateral pyramidotomy in NgR1null mice (Cafferty and Strittmatter, 2006). The beneficial effect of NgR1 ablation in some CNS tracts could be masked by other inhibitory factors such as the glial scar and chondroitin sulfate proteoglycans. These observations are a useful reminder of the limitations of translating in vitro assays to the more complex in vivo situation.

\section{References}

Ahmed Z, Dent RG, Suggate EL, Barrett LB, Seabright RJ, Berry M, Logan A (2005) Disinhibition of neurotrophin-induced dorsal root ganglion cell neurite outgrowth on CNS myelin by
siRNA-mediated knockdown of NgR, p75NTR and Rho-A. Mol Cell Neurosci 28:509-523.

Cafferty WB, Strittmatter SM (2006) The NogoNogo receptor pathway limits a spectrum of adult CNS axonal growth. J Neurosci 26:12242-12250.

Chivatakarn O, Kaneko S, He Z, Tessier-Lavigne M, Giger RJ (2007) The Nogo-66 receptor $\mathrm{NgR} 1$ is required only for the acute growth cone-collapsing but not the chronic growthinhibitory actions of myelin inhibitors. J Neurosci 27:7117-7124.

Fournier AE, Gould GC, Liu BP, Strittmatter SM (2002) Truncated soluble Nogo receptor binds Nogo-66 and blocks inhibition of axon growth by myelin. J Neurosci 22:8876-8883.

GrandPre T, Li S, Strittmatter SM (2002) Nogo-66 receptor antagonist peptide promotes axonal regeneration. Nature 417:547-551.

Kim JE, Liu BP, Park JH, Strittmatter SM (2004) Nogo-66 receptor prevents raphespinal and rubrospinal axon regeneration and limits functional recovery from spinal cord injury. Neuron 44:439-451.

Li S, Liu BP, Budel S, Li M, Ji B, Walus L, Li W, Jirik A, Rabacchi S, Choi E, Worley D, Sah DW, Pepinsky B, Lee D, Relton J, Strittmatter SM (2004) Blockade of Nogo-66, myelin-associated glycoprotein, and oligodendrocyte myelin glycoprotein by soluble Nogo-66 receptor promotes axonal sprouting and recovery after spinal injury. J Neurosci 24:10511-10520.

Vyas AA, Patel HV, Fromholt SE, Heffer-Lauc M, Vyas KA, Dang J, Schachner M, Schnaar RL (2002) Gangliosides are functional nerve cell ligands for myelin-associated glycoprotein (MAG), an inhibitor of nerve regeneration. Proc Natl Acad Sci USA 99:8412-8417.

Wang KC, Kim JA, Sivasankaran R, Segal R, He Z (2002) P75 interacts with the Nogo receptor as a co-receptor for Nogo, MAG and OMgp. Nature 420:74-78.

Winton MJ, Dubreuil CI, Lasko D, Leclerc N, McKerracher L (2002) Characterization of new cell permeable C3-like proteins that inactivate Rho and stimulate neurite outgrowth on inhibitory substrates. J Biol Chem 277:32820-32829.

Zheng B, Atwal J, Ho C, Case L, He XL, Garcia KC, Steward O, Tessier-Lavigne M (2005) Genetic deletion of the Nogo receptor does not reduce neurite inhibition in vitro or promote corticospinal tract regeneration in vivo. Proc Natl Acad Sci USA 102:1205-1210. 